\title{
Hidronefrosis bilateral con riñón ectópico pélvico.
}

\author{
Fuentes S, Herranz Amo F, Hernández Fernández C.
}

Servicio de Urología Hospital General Universitario Gregorio Marañón. Madrid.

Actas Urol Esp. 2007;31(4):430

$\mathrm{M}$ ujer de 40 años que es estudiada tras hallazgo de agenesia renal izquierda en ecografía ginecológica y es diagnosticada mediante tomografia axial computerizada (TAC) y estudio isotópico de hidronefrosis bilateral con riñón ectópico pélvico no funcionante. Actualmente se encuentra asintomática y en seguimento en consultas de Urología.

Una mujer de 40 años sin antecedentes personales médicos o quirúrgicos de interés, presenta como únicos antecedentes urológicos una historia de infecciones del tracto urinario no complicadas y de crisis renoureterales izquierdas de repetición, aproximadamente dos episodios al año, no expulsivos. Acude a nuestra consulta por hallazgo en ecografia ginecológica rutinaria de agenesia renal izquierda y probable riñón ectópico en pelvis menor. La paciente se encuentra asintomática y refiere unicamente molestias abdominales en situación de teórico riñón izquierdo. Tanto la exploración física como las analíticas de sangre y orina son normales. El
TAC abdominal muestra hidronefrosis bilateral con riñón derecho ortotópico e izquierdo ectópico pélvico. En riñón derecho el origen de la hidronefrosis parece ser una estenosis de la unión pieloureteral en relación con un cruce vascular tanto arterial como venoso. En el riñón pélvico se objetiva dilatación pielocalicial, sin que se aprecie causa de la misma. En el estudio isotópico se observa una morfología renal derecha conservada con probable dilatación de estructuras pielocaliciales y con un patrón pseudoobstructivo con discreta alteración funcional y riñón izquierdo de situación intrapélvica, desestructurado y con severa alteración funcional.

En el momento actual se decide control periódico en nuestras consultas de Urología.

Correspondencia autor: Dra. S. Fuentes

Servicio de Urología Hospital General Universitario Gregorio

Marañón. Dr. Esquerdo, 46. 28007 Madrid. Tel.: 915868000

E-mail autora: sarafuentes@yahoo.es

Información artículo: Imágenes en Urología

Trabajo recibido: marzo 2006

Trabajo aceptado: abril 2006

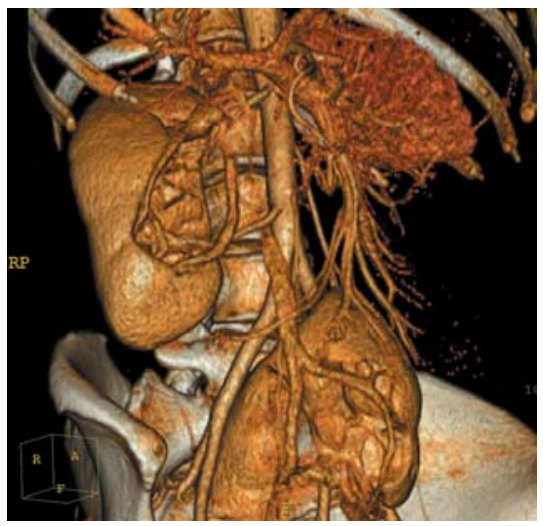

FIGURA 1

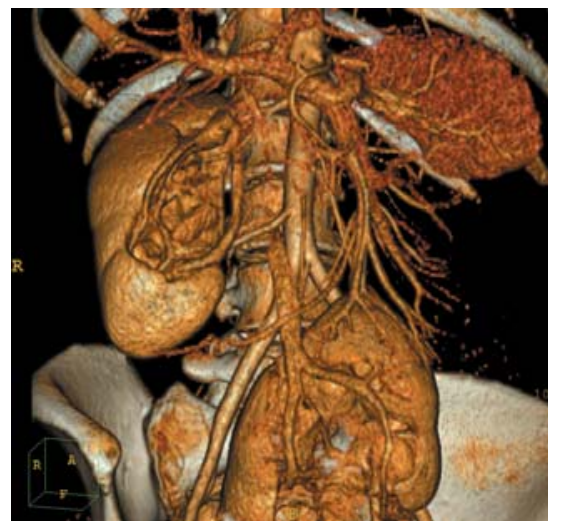

FIGURA 2

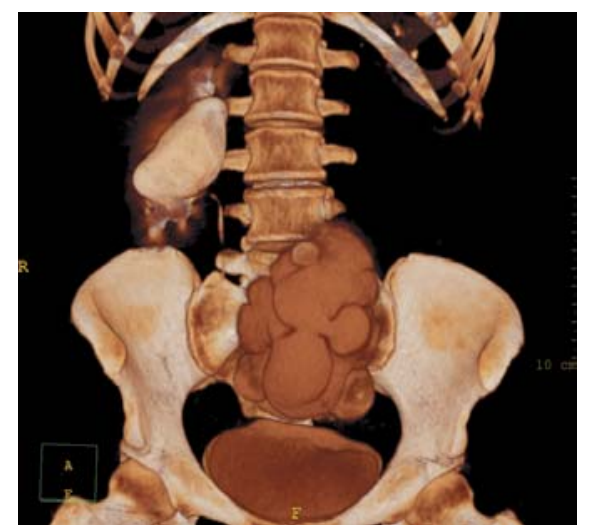

FIGURA 3 